\title{
日光国立公園戦場ヶ原湿原における保全意識の変遷に関する研究
}

\section{A Study on Changes of the Conservation Consciousness on Senjogahara Moor in Nikko National Park}

\author{
番匠 克二* 手嶋 潤一** 堀 繁*** \\ Katsuji BANSHO Jyunichi TESHIMA Shigeru HORI
}

\begin{abstract}
Senjogahara Moor had been visited botanists and many tourists for a long time and is the one of the moor where relations with the human being are particularly strong in Japan. This study clarified changes of conservation consciousness on Senjogahara Moor from the Meiji period to the Showa period by various documents. As a result, it became clear as follows: (1) Importance of Senjogahara Moor was already discovered by botanists in the Meiji period, and conservation consciousness already occurred to botanists during the Taisho period. (2) The national park administration kept conservation consciousness continuously while being affected by the thought of the sightseeing promotion, from the designation of the national park to about 1965. (3) Senjogahara Moor was recognized as a place of the comfortable scenery and the tourism development from the Taisho period, conservation consciousness is not watched besides botanists and the national park administration until about 1965. (4) Change to positive conservation consciousness that national park administration took conservation measures was watched from about 1965, and it changed measures of other people and organizations.
\end{abstract}

Keywords: national park, Senjogahara, moor conservation, special protection zone キーワード：国立公園，戦場ヶ原，湿原保全，特別保護地区

\section{1. はじめに}

杤木県の北西部に位置する戦場ヶ原湿原は，男体山をはじめと する山々に囲まれた海抜約 $1400 \mathrm{~m}$ の緩やかに傾斜のある平坦地 で，その面積は約 400ha である。戦場ヶ原では，中間湿原を中心 として, 高層湿原から低層湿原にわたる多様な湿原植生の発達が 見られ，古くから多くの植物学者が研究の場として訪れている。 その一方で, 戦場ヶ原湿原は, 首都圈から近く古くから道 (現在 の国道 120 号線）が湿原の中を通り，利便性が高、場所であった こともあり，さまざまな保全上の問題が発生してきている。こう した貴重な自然が大きな利用圧力にさらされているという背景か ら，戦場ヶ原は，わが国の湿原の中でも早い時期から有識者によ って湿原の保全が指摘された場所であり，貴重な自然を保全する 意識が早くから生まれた場所であるといえる。

戦場ヶ原湿原では，さまざまな調査研究が行われており，保全 対策に関する研究 1), シ力対策に関する研究 2), 日光戦場ヶ原湿 原周縁部における植生変化を明らかにした研究 3)，戦場ヶ原での 水の挙動についての研究 ${ }^{4)}$, 行政機関による調査 ${ }^{5)}$ ほか多数の調 査研究がある。また, 日光国立公園の日光地域の歴史に関しては, 公園成立の経緯を明らかにした研究 6 (6) 7 ，レクリエーション利用の

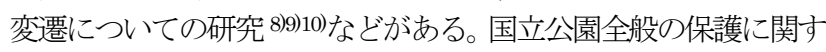
る研究については, 国立公園の特別保護地区の実態と変遷を明ら かにした研究11)がみられる。

しかしながら，国立公園の重要な自然資源の保護に関してその 背景の保全意識を過去にさかのぼって明らかにしたものは少なく， 古くから多くの関係者が注目し, 多くの保全上の問題が発生して きている戦場ヶ原湿原においても，背景にある保全意識を通史的 に明らかにしたものはない。

そこで, 本研究は, 戦場ヶ原湿原における明治期から昭和期ま での保全意識の変遷を明らかにする。それにより現在当然と考え られている湿原保全の取り組みの背景となる保全意識の発現過程 を明らかとし，今後の戦場ヶ原湿原の保全のための参考となる知
見を得る。また，こうした戦場ヶ原湿原のように古くからさまざ まな考えをもとに，利用され，保全されてきた地域の意識を明ら かにすることは, わが国の自然保護の考え方がどのように発展し, 変遷してきたかを知る蓄積の一つともなる。

研究の方法としては, 戦場ヶ原湿原に関する明治期以降の各種 文献，新聞記事や行政資料を収集し，その内容から当時の意図を 読み取ることにより行った。その際，専門家の意識及び技術行政 官により専門家の意見が反映されることの多い国立公園行政

（1931(昭和 6)年以降）の意識と，それ以外の地域住民の意見が 反映されやすい地方行政や他分野の行政機関の意識及び一般利用 者の意識が一致しているわけではないことから，それぞれの保全 意識を捉え（表一 1$)$ ，それらの関係についても考察を行った。

\section{2. 明治期の保全意識}

日光は，古くから植物の宝庫として植物学者が訪れていた地域 であり，日本の高山植物の研究は日光の植物から始まったといわ れている 12)。特に, 1877(明治 10)年に東京大学が設立され, 初代 の植物学教授である谷田部良吉が最初の調査地として日光を選ん で以降，同大学の白井光太郎，牧野冨太郎，松村任三などが戦場 ケ原をはじめとする奥日光を訪れて植物の調査を行っている。こ うした中で，もともと植物の宝庫であった日光において植物の調 查研究が進められ, 1894(明治 27)年に戦場ヶ原で見られる多くの 植物を含む日光産の植物を扱った最初の目録である「日光山植物 目録」13)が出されるなど認識が高まっていくこととなる。そして, 1902(明治 35)年に高山植物や寒冷地の植物の研究と教育のため 東京帝国大学理科大学附属植物園日光分園が設置され, 当時の植 物の専門家の多くが日光を訪れることになる。

一方で, 既に 1878(明治 11)年には, 戦場ヶ原に最初の開拓が入 っており, 当時の新聞14)では戦場ヶ原について「県庁にても無顧 の地」と記され,「許可のうえ種代, 農具料を下与」したとされて

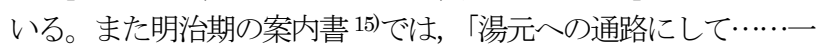

\footnotetext{
*環境省関東地方環境事務所 **アクリーグ株式会社 ***東京大学アジア生物資源環境研究センター
} 
里ばかりの原野なり」との記述でしかなく, 1911(明治 44)年に編 纂された日光町史 16)でも，「戦場ケ原の平地あり」と記述される のみで，他の中禅寺湖などの記述に比へ，何も記載されていない に等しい状況となっている。同じく 1911(明治 44)年に初めて出さ れた日光町長による「日光山ヨ大日本帝国公園卜為スノ請願」に おいても中禅寺湖畔, 湯元温泉, 湯ノ湖辺について記載されてい るものの, 戦場ヶ原について記述はない。

このように明治期においては, 1890(明治 23)年に日光駅まで鉄 道が開通し, 1902(明治 35)年頃からは人力車がいろは坂を通るよ うになり, 東京から近い植物の宝庫として専門家が足繁く通い, その貴重性が認識されていった一方で，一般的には戦場ヶ原の存 在の認識すら薄く, 戦場ヶ原の開拓が何の検討もなく認められる などの状況であったことがわかる。

\section{3. 大正期の保全意識}

大正にはいると, 白井光太郎により「不殺生, 不伐木, 不開拓」 という今の自然保護のような論がなされる ${ }^{17) こ と に な る 。 そ の な ~}$ かで, 戦場ヶ原については, 「景色のみでも, 保存の価值があるが, 其他植物学上, 地質学上, 教ゆる所の多い場所であって, 決して 破壊してはなら所であります」としたうえで,「今や馬車, 自動 車, 荷車のために, 散々に破壊せられ, 又さらに破壊せられんと して居る。見苦しき牧舎, 見苦しき開拓小屋は……不快の感を与 えつつある。と既に大正初期に自然破壊を嘆いている。
一方，1914(大正 3)年の杤木県知事による「日光経営二関スル 意見」においては,「殊二戦場尔原ノ如キ海抜四千六百尺一望空濶 亘々タル高原地ニシテ風光雄大頗ル外人ノ趣味二適スルモノア リ」と記述され，具体的な事業計画として，「戦場ケ原ニ，ゴルフ グラウンド，野球場，庭球場，其他ノ遊戯場フ設置スルコト」と の記述がある。日光は外国人の来訪も多く, 明治の中期からは中 禅寺湖畔に外交官が擗暑に訪れており，こうした外国人の利用を 増やすことを目的に整備の計画がたてられたものと考えられる。 これは，同じ 1914(大正 3)年に作成された日光町長による「日光 山ヨ大日本帝国公園卜為ス/請願書」において「珍草奇花及四面 絶大ノ風致二富メル戦場厅原ノ如キ… (中略) …絶勝佳景ノ地

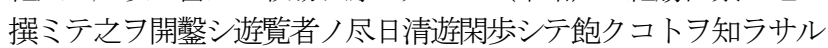
娛楽場ヨ増設スルノ急ナルニ如カサルナリ」というそれまでの請 願にない事項が入っていることに繋がっているものと考えられる。 また, 大正期の案内書 18$)$ では, 「原の大部分は湿地で......百花一 時に爛漫として」との記述となっており,一般向けの案内におけ る認識も明治期とは大きく異なっている。

つまり，1913(大正 2)年に電気鉄道が日光駅から馬返まで延長 されるなど奥日光へのアクセスが改善され，奥日光の利用者が増 加して自然破壊が見られるようになったことに対し専門家が早く も自然を保護することの重要性を訴え始めており，保全意識の発 現を伺うことができる。その一方で，交通機関の整備を背景に戦 場ケ原に対する認識は高まったものの, 特に国際観光の推進とい

表-1 保全意識と保全意識に二関わる事実・文献等

\begin{tabular}{|c|c|c|c|c|c|c|}
\hline & \multicolumn{2}{|c|}{ 専門家, 国立公園行政 } & & \multicolumn{2}{|c|}{ 地方 - 他分野行政，一般利用者 } & \multirow{2}{*}{ 交通・社会状況 } \\
\hline & 事実·文献等 & 保全意請 & & 全全意識 & 事実・文献等 & \\
\hline $\begin{array}{l}\text { 琞 } \\
\text { 㵅 }\end{array}$ & $\begin{array}{l}\text { (1894) 日光山植物目録: 松村任三 } \\
\text { (1902) 東大植物園日光分園設置, } \\
\text { 以降植物学の䒠習場所として日 } \\
\text { 光が利用される。 }\end{array}$ & \begin{tabular}{|l|} 
認識の \\
発生 : \\
植物の \\
貴重性
\end{tabular} & & & $\begin{array}{l}\text { (1911) 日光町史 :「戦場ヶ原の平 } \\
\text { 地あり」の記述 } \\
\text { (1911)帝国公園請願 : 日光町長 }\end{array}$ & 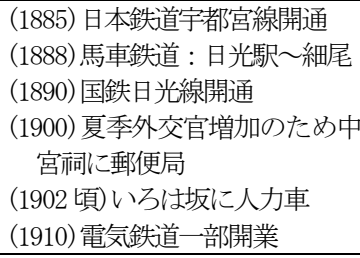 \\
\hline $\begin{array}{l}\text { 齿 } \\
\text { 期 }\end{array}$ & $\begin{array}{l}\text { (1915)植物學上より觀たる日光: } \\
\text { 白井光太郎 }\end{array}$ & \begin{tabular}{|l|} 
保全意 \\
識の発 \\
現
\end{tabular} & & $\begin{array}{l}\text { 認識の } \\
\text { 発生 : } \\
\text { 冷涼で }\end{array}$ & $\begin{array}{l}\text { (1914) 日光経営二関スル意見 : } \\
\text { 杤木県 } \\
\text { (1914) 帝国公園請願 : 日光町長 } \\
\text { (戦場ヶ原の記述) }\end{array}$ & $\begin{array}{l}\text { (1913)電攵鉄道 : 日光駅〜馬返 } \\
\text { (1925) いろは坂自動車通行可能 } \\
\text { に }\end{array}$ \\
\hline $\begin{array}{l}\text { 照 } \\
\text { 初 } \\
\text { 期 }\end{array}$ & $\begin{array}{l}\text { (1931) 国立公園法施行 } \\
\text { (1934) 日光国立公園指定 } \\
\text { (1935) 日光國立公園施設計畫案： } \\
\text { 杤木県 } \\
\text { (1938)国立公園行政厚生省体力局 } \\
\text { 所管に } \\
\text { (1940) 日光國立公園一般計畫案 : } \\
\text { 厚生省 }\end{array}$ & $\begin{array}{l}\text { 保 } \\
\text { 㝨 } \\
\text { 識 }\end{array}$ & 戦 & $\begin{array}{l}\text { 開放的 } \\
\text { 風景= } \\
\text { 国際観 } \\
\text { 光適地 }\end{array}$ & 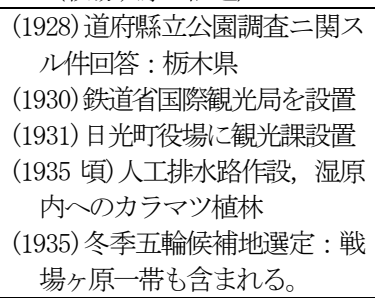 & 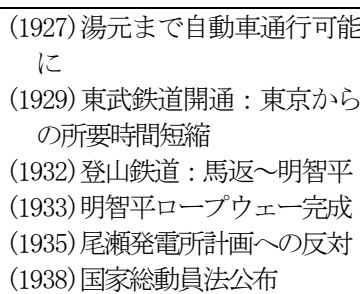 \\
\hline $\begin{array}{l}\text { 照 } \\
\text { 虫 } \\
\text { 期 }\end{array}$ & $\begin{array}{l}\text { (1946) 日光國立公園施設計畫概要 } \\
\text { 書 : 杤木県 } \\
\text { (1947)国立公園法施行規則改正 : } \\
\text { ゴルフ場等を事業施設に } \\
\text { (1949) 国立公園法改正 : 特別保護 } \\
\text { 地区制度等の追加 } \\
\text { (1949) 公園計画決定 : 隣接する小 } \\
\text { 田代原にコルルフ場 } \\
\text { (1954) 三本松に本止め設置 } \\
\text { (1957)特別保護地区に指定 }\end{array}$ & $\begin{array}{l}\text { 極 } \\
\text { 的 } \\
\text { ॥ } \\
\text { 計 } \\
\text { 画 } \\
\text { 策 } \\
\text { 定 }\end{array}$ & 害 & $\mid$\begin{tabular}{|c} 
認識: \\
際観 \\
光・復 \\
興一観 \\
光開発 \\
産業 \\
の対象
\end{tabular} & 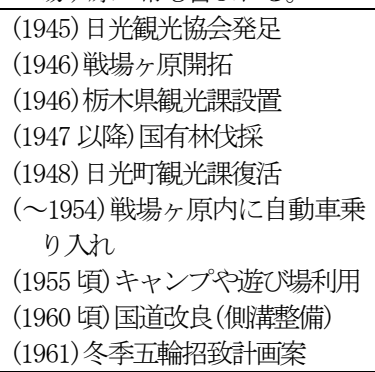 & 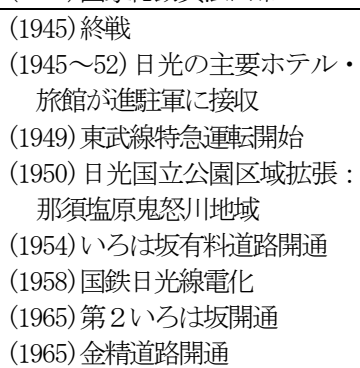 \\
\hline $\begin{array}{l}\text { 照 } \\
\text { 稸 } \\
\text { 期 }\end{array}$ & $\begin{array}{l}\text { (1967) オオハンゴンソウ除去開始 } \\
\text { (1969) 湿原内立入禁止 : 三本松展 } \\
\text { 望台整 } \\
\text { (1968) 県による植生調查 } \\
\text { (1970) 貝による地地地質調査 } \\
\text { (1974) 排水路への遮水堰設置 } \\
\text { (1982) 乾燥化の実態と対策調査 }\end{array}$ & $\begin{array}{l}\text { 保全意 } \\
\text { 識 : 積 } \\
\text { 極的= } \\
\text { 保全対 } \\
\text { 策実施 }\end{array}$ & & $\begin{array}{l}\text { 保全意 } \\
\text { 識 : 他 } \\
\text { 分野行 } \\
\text { 政等へ } \\
\text { の波及 }\end{array}$ & 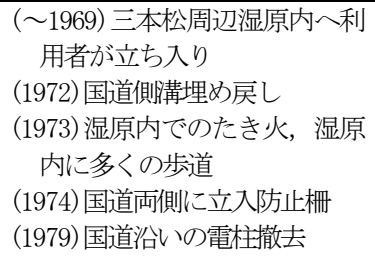 & 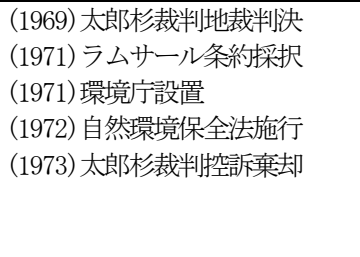 \\
\hline
\end{tabular}


う背景のもとで，地方行政においては娛楽場や遊戯場といった開 発により観光客を増やすことが優先的に考えられており，保全意 識はまだなかったものといえる。

\section{4. 昭和初期 (戦前) の保全意識}

1925(大正 14)年にいろは坂を自動車が通行可能になり, 1927(昭和 2)年までには戦場ヶ原を通って湯元まで自動車で行け るようになった。そして，1929(昭和 4)年には東武鉄道が東武日 光駅まで開通し東京からの所要時間が短縮され，1932(昭和 7)年 に馬返〜明智平のケーブルカーが開通するなど奥日光への交通は 著しく便利になっている。そうしたなかで，1931(昭和 6)年に国 立公園法が施行され，国立公園行政が始まる。法の制定にあたつ ては, 「外客誘致に資し国際貸借改善上寄与せしめんとする経済的 使命」，「国立公園は風景を資源とする一種の産業」19)といった認 識が示されている。ところが，1934(昭和 9)年の国立公園指定後 の 1935(昭和 10)年に杤木県によりまとめられた「日光國立公園 施設計畫案」では, 戦場ヶ原に次に記述する 1928(昭和 3)年の「道 府縣立公園調査二関スル件回答」のような運動施設は計画されて いない。野球場, ゴルフ場, 乗馬施設, 総合運動場といった施設 は，霧降地区に計画されており，国立公園行政としては戦場ヶ原 に運動施設を受け入れなかったことがわかる。さらに，1940(昭 和 15)年に厚生省が作成した「日光國立公園一般計畫案」におい ては，戦場ヶ原は隣接する小田代原とともに沼野植物群落の保存 のための保存地区 20) とされている。この後, 戦時体制が強まり, 公園行政が停滞したため, 本案は決定されないまま21) となった。

一方，1928(昭和 3)年に内務省衛生局長の照会に対応して杤木 県知事から「道府縣立公園調査二関スル件回答」が出されている。 この文書では，戦場ヶ原・小田代原に「野球場，庭球コート，馬 場，大弓場，身撃場，陸上競技場，ゴルフリンクス，競馬場」が 計画されている。1914(大正 3)年の「日光経営二関スル意見」と 比べてもさらに拡充された開発計画となっていることがわかる。

また, 1935(昭和 10 年)頃までには, 戦場ヶ原に湿原からの排水 を促すための人工排水路が作設されるとともに, 湿原内へカラマ ツの植栽が行われ 22)，1935(昭和 10)年の冬季五輪候補地選定 (札 幌に決定，後に中止。）時に日光が立候補した際には, 戦場ヶ原一 帯も整備地とされていた23)。

このように，国立公園法は国際観光推進の考えの影響を受けて 成立したが，杤木県において戦場ヶ原を大規模に観光開発する計 画がたてられたにも関わらず，その後の国立公園行政においては 戦場ヶ原を保存する計画をたてていることがわかった。これは， 国立公園が国際観光推進の役割を担いながらも戦場ヶ原の学術的 な重要性を国立公園行政が強く認識していた 24)ためではないか と考えられる。そして，1938(昭和 13)年には戦争の流れのなかで 国立公園は国民鍛錬の場として位置づけられ，国立公園行政が厚 生省体力局の所管となり, 国際観光地整備の考えがなくなったこ とで, 沼野植物群落の保存地区への位置づけという形で保全意識 が表に出てきたといえる。一方，国立公園行政以外では，大正期 に引き続く大規模な利用施設の整備計画, 湿原内へのカラマツ植 林，冬季五輪の整備候補地といったように，戦場ヶ原はあくまで 観光・産業利用の対象地という認識であったと考えられ，保全意 識はなかったことがわかる。

\section{5. 昭和中期（戦後 1965 (昭和 40) 年頃) の保全意識}

戦後すぐの 1946(昭和 21)年には, 国立公園行政を担っていた 杤木県が「日光國立公園施設計畫概要書」を作成している。この 文書は，1940(昭和 15)年の「日光國立公園一般計畫案」に準拠し て作成されたものとされている。しかしながら，「日光國立公園一 般計畫案」では戦場ヶ原周辺に計画されていなかったゴルフ場に
つい,「公園内滞在者特二外國人二八必要ナル施設」として小田 代原, 戦場ヶ原, 千手ヶ浜のいずれかに 1 箇所という形で取り上 げられている。1947(昭和 22)年に国立公園法施行規則が改正され 事業施設として, ゴルフ場, スキ一場, 乗馬施設, 舟遊場が追加 されたように，進駐軍の駐留も背景に外国人の利用のための施設 が求められていたことへの対応であったといえよう。日光国立公 園の公園計画は，戦前に一部が決定されていたものの全体につい ては決定されないままであった。それが，1949(昭和 24)年に保護 計画（特別保護地区を除く。）と利用計画が決定され，1957(昭和 32)年に特別保護地区の計画が決定される。この日光国立公園の公 園計画によると, 戦場ヶ原は沼野植物群落の保護のために特別保 護地区に指定をされている。しかし，1940(昭和 15)年の「日光國 立公園一般計畫案」において, 同じく保存地区とされていた戦場 ケ原に隣接する小田代原にはゴルフ場が計画されている。これは 外国人の利用を意識してゴルフ場を計画する際に比較的草原に近 い環境を持ち専門家の注目度も低い小田代原を選び，それにより 戦場ヶ原を特別保護地区とすることができたものと考えられ, 戦 後すぐの観光振興と保全のせめぎあいを感じさせる。

一方, 戦場ヶ原においては, 1946(昭和 21)年に県により開拓者

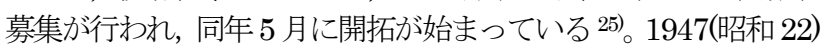
年には御料林が国有林に編入され，大規模伐採が始まる 26$)$ 。乙 て, 戦後の復興とともに日光一の観光客が急速に増え, 特にバス, 自家用車で訪れる人の数が増加 ${ }^{27)}$ する。1954(昭和 29)年までは戦 場ヶ原湿原の中に車で乗り入れることも可能であった ${ }^{28)}$ 。また, 戦場ヶ原では 1960(昭和 35)年頃までは, 湿原に自由に立ち入る ことが普通であり，キャンプや遊び場として使われていた ${ }^{29)}$ 。そ の結果, 戦場ヶ原には多くの人が立ち入ることによる裸地が広が り, 特に売店や駐車場があった三本松周辺には大きな砂地の場所 が発生していた。また，1960(昭和 30)年頃には国道の改良が行わ れ，大規模な盛土により整備が行われるとともに，その後湿原か らの排水を促進するものとして批判される側溝が掘られた。そし て, 1961(昭和 36)年に日光市が中心となって冬季五輪を招致する ために作成した計画 30 には, 周囲の外山から戦場ヶ原に向けて滑 り降りるコースや小田代原の選手村の建設計画が含まれていた。

つまり, 国立公園行政としては, 戦後駐留軍の将校が休養地と して日光に多数滞在していたことも背景に, 国際観光推進の影響 を大きく受けながらも, 戦場ヶ原については保全すべき場所とい う位置づけを守った。しかし，単に計画として指定したのみに留 まり，車の乗り入れは車止めの設置により制限したものの，急増 する利用者による荒廃や観光・産業振興のための開発に歯止めを かけることはできず，いわば消極的な保全意識を持つに留まった ということができよう。一方で国立公園行政以外においては，自 然を求めて非常に多くの人々が訪れるようになったにも関わらず, 昭和初期に引き続き保全意識はみられないことがわかった。

\section{6. 昭和後期 (1965 (昭和 40) 年頃 ） の保全意識}

1963(昭和 38)年には, 「乾燥が草原化早める」「湿原保護へ」と いう記事が下野新聞に掲載 31)される。この記事は, 1968(昭和 43) 年以降に実現する杤木県の調査について書かれたものと思われ， 戦場ヶ原湿原の乾燥化について初めて取りあげたものである。こ の調查の報告書32)では, 踏圧により生じた裸地復元といった利用 者対策を中心に湿原保護のための対策が提案される。実際, 展望 台や木道などの利用施設を整備し, 立入禁止の措置を浸透させ, 植生復元のための植栽をすることで対策を図っている。また, 1967(昭和 42)年には, 外来植物であるオオハンゴンソウの除去が 関係者により始められ，1974(昭和 49)年には，戦前に作設された 排水路への遮水堰の設置が行われるなど個別の問題に対応する対 策が実施された。その後, 継続的に戦場ヶ原における詳しい調査 
が実施される一方で, 1990 年代には総合的な湿原保全対策が杤木

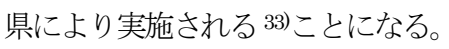

一方，湿原からの排水を早めるものとして批判されていた国道 の側溝が道路部局により 1972(昭和 47)年に埋め戻された。また, 1973(昭和 48)年には，まだ湿原内でのたき火や湿原内の歩道がみ られることが指摘されながらも，三本松周辺の湿原に利用者が立 ち入らなくなったことにより，徐々に植生が戻りつつあることが 記録 34 されている。また，1974(昭和 49)年には，国道両側に整備 された歩道に柵が設置され, 湿原への立入防止措置が実施された。 そして 1979(昭和 54)年には，戦場ヶ原を縦断していた国道沿い の電柱も移設・撤去が行われた。

つまり，急増した利用者により大きな裸地（砂地）が発生する といった湿原の荒廃がみられ，それに対応した対策が徐々に行わ れるなかで, 1963(昭和 38)年に湿原ということを明確に意識した 乾燥化というキーワードがみられることが注目される。この乾燥 化という現象に対して調査が継続的に行われ，保全対策が実施さ れていくこととなるが，こうした積極的な保全意識が 1965(昭和 40)年頃から芽生えたと考えられる。そして，1971(昭和 46)年の 環境庁発足に代表される環境保全意識の高まりもあいまって，国 立公園行政以外の者の保全意識の顕在化を促し，国道における側 溝の埋め戻しや侵入防止柵の設置, 戦場ヶ原内の電柱の撤去など, 他の分野への保全意識の広がりにつながっていったと考えられる。

\section{7. まとめ}

本研究では, わが国の湿原でも古くから専門家が訪れるととも に活発な観光利用が行われ，さまざまな形で人の関与を受けてき た戦場ヶ原湿原を対象に, 保全意識の変遷について明らかにした。 戦場ヶ原は，明治期において先駆的な植物学者に注目され，そ の重要性が発見されており，大正期には自然破壊が指摘され，自 然保護論が述べられるようになっている。一般的にはまだ戦場ケ 原の認知度は低かったものの，既に大正時代の早い時期から保全 意識が生じていた。

また，その意識がその後昭和期に入って国立公園行政へと引き 継がれ，昭和のはじめの国際観光推進の考え方や，戦後すぐの戦 後復興と観光開発の影響を大きく受けながらも，戦場ヶ原におい ては保全意識を継続的に保持しながら各種の計画を策定し， 1957(昭和 32)年特別保護地区の指定につながったといえる。しか し，この頃までは，計画として指定しただけに留まり，消極的な 保全意識といっても良いものであった。

国立公園行政以外の側では，交通機関の発達や国立公園候補地 としての請願により大正時代の頃から戦場ヶ原の風景が認知され たが，国際観光推進の考え方から冷涼で開放的な風景をもつ整備 適地としての捉え方が強く，大規模な開発が計画された。また， 戦前のカラマツ植林のための排水路作設や，戦後の開拓や側溝の 整備が行われるなど湿原についての保全意識は 1965(昭和 40)年 頃まではみられない。特に，戦後の利用者の急増期に，保全意識 のない利用者により湿原の荒廃が進むこととなった。

こうした湿原の荒廃を背景に，1965(昭和 40)年頃からは，乾燥 化というキーワードが使用され，保全のための調査や対策を実施 するという積極的な保全意識が国立公園行政側に顕在化していく こととなった。そして, それが国立公園行政以外の側にも波及し， 保全意識が広がっていくこととなった。

以上のように保全意識が変遷した結果, 現在では地元自治会の 外来種除去の取り組みやボランティアによる自然調査など多くの 人々が戦場ヶ原及びその周辺の保全に参加するようになっている。 昭和期までは専門家や国立公園行政側の保全意識が先に発現して きているが, 現在は保全意識に大きな違いがない状況もみられる。 そのため, 今後の戦場ヶ原をはじめとする自然環境の保全にあた
っては，これまでの国立公園行政が先導する形ではなく，こうし た保全意識を持つ人との協働が重要になってきているものと考え られる。

\section{補注及び引用文献}

1）番匠克二(2009) : 戦場ヶ原における湿原保全対策の変遷とその方針に関寸る研究 : ランドスケープ研究 72(5),557-560

2）番匠克二・雨宮俊(2010) : 日光国立公園戦場ヶ原湿原におけるシ力対策の変遷に関 する研究 : ランドスケープ研究 73(5),509-512

3）福嶋司・吉川正人·谷川敦子・奈良遥(2007) : 過去 25 年間の日光戦場ヶ原湿原周縁 部における植生変化追跡 : プロ・ナトゥーラ・ファンド第 16 期助成成果報告書

4) 平山光衛・鈴木陽雄(1984) : 戦場ヶ原盆地における水の挙動について : 宇都宮大学 教育学部紀要 35,131-144

5）後掲 22)や下野地学会(1982) : 環境庁業務委託事業「日光国立公園戦場ヶ原湿原の乾 燥化の実態と対策調査報告書」など各種報告書がある。

6）手嶋潤一・堀繁(1994）: 国立公園成立期における日光地域の風景の利用と保護に関 寸る研究 : 造園杂位志 $57(5), 85-90$

7）手嶋潤－(1992）: 日光国立公園一成立に関寸る一考察一(1)（4)：国立公園 502,2-9, 国立公園 503,2-7,国立公園 504,2-11,国立公園 505,10-15

8）永嶋正信(1985) : 日光地域の野外レクリエーション利用の変遷に関寸る研究(1868 年〜1931年まで) : 造園䧱誌 $48(5), 25-30$

9）永嶋正信(1986) : 政策・社会の動きからみた日光地域の野外 Rec.利用の変遷に関す る研究(1931 1950) : 造園杂位志 49(5),25-30

10）永嶋正信(1987) : 政策・社会の動きからみた日光地域の野外レクリエーション利用 の変遷に関する研究(1950 1975) : 造園杂隹志 50(5),60-65

11）堀繁・鑪迫ますみ(1992)：特別保護地区にみる国立公園保護計画の思想とその変 遷 : 造園杂隹誌 55(5),241-246

12）大場秀章(1988): 日光地方の植物研究の歴史: 杤木県立博物館研究報告書特別号日 光の動植物 $(\mathrm{V}), 1-52$

13) 松村任三(1894) : 日光山植物目録 : 石川茂夫,93pp

14) 杤木新聞(1879) : 明治 12 年 9 月 1 日

15）島村忠次郎(1899) : 日光名勝案内記 : 鈴木角太郎,68pp

16) 日光尋常高等学校編纂(1911) : 日光町史 I (第一編 自然界)

17）白井光太郎(1915) : 植物學上より觀たる日光 : 画報社 : 日光, $66-122$

18）高野豊三郎(1919) : 日光遊覽釈 : 三楽園,71pp

19）伊藤武彦(1931）：国立公園法解説 : 国立公園協会,196pp

20）保存地区は国立公園法に規定がないが，1937(昭和 12)年の「國立公園計畫標準」(内 務省衛生局)で計画に定める事項として「保存地區卜稱スルハ特別地域内二於テ一定 ノ地區习劃シ特定ノ自然物, 自然現象又八史蹟等习保存スル地區习謂つ」とされた。 21）手嶋潤一(2006) : 日光の風景地計画とその変遷 : 随想舎,398pp

22）久保田秀夫 - 松田行雄 ・波田善夫(1978) : 日光戦場ヶ原湿原の植物 : 杤木県林務観 光部環境観光課, $132 \mathrm{pp}$

23）日光市史編さん委員会(1979): 日光市史 下巻 : 日光市,1239pp

24）当時の「國立公園ノ選定二關スル特別委員會」委員は戦場ヶ原について「日光國立 公園の價值をして幾層倍ならしめてみるかも知れぬ」と記述している。脇水鐵五郎 (1932):地學上より見たる國立公園候補地[八]:國立公園 4(3):國立公園協會, $2-6$

25）吉津谷忍 - 道上猛・ 小出太美・加藤成二(1976) : 戦場ヶ原開拓誌 : 戦場ヶ原開拓三 十周年記念事業実行委員会, $227 \mathrm{pp}$

26) 日光の動植物編集委員会(1986)：日光の動植物 : (株)杤の葉書房,739pp

27）前掲 23)

28）杤小新聞(1973)：日光の風化と浸食N No.26

29）前掲 22)

30）日光市役所(1971) : 日光市広報 4 月号 : 日光市, $2 p p$

31) 下野新聞(1963) : 昭和 38 年 10 月 18 日

32）財団法人国立公園協会 (宮脇昭他)（1969）：日光戦場ヶ原の植生調査報告書: 国立 公園協会, $37 \mathrm{pp}$

33）前掲 1)

34) 杤木新聞(1973)：日光の風化と浸食No.25,26 